\title{
Modelling tissues in 3D: the next future of pharmaco-toxicology and food research?
}

\author{
Giovanna Mazzoleni · D. Di Lorenzo • \\ N. Steimberg
}

Received: 11 September 2008/Accepted: 25 November 2008/Published online: 18 December 2008

(C) Springer-Verlag 2008

\begin{abstract}
The development and validation of reliable in vitro methods alternative to conventional in vivo studies in experimental animals is a well-recognised priority in the fields of pharmaco-toxicology and food research. Conventional studies based on two-dimensional (2-D) cell monolayers have demonstrated their significant limitations: the chemically and spatially defined three-dimensional (3D) network of extracellular matrix components, cell-to-cell and cell-to-matrix interactions that governs differentiation, proliferation and function of cells in vivo is, in fact, lost under the simplified 2-D condition. Being able to reproduce specific tissue-like structures and to mimic functions and responses of real tissues in a way that is more physiologically relevant than what can be achieved through traditional 2-D cell monolayers, 3-D cell culture represents a potential bridge to cover the gap between animal models and human studies. This article addresses the significance and the potential of 3-D in vitro systems to improve the predictive value of cell-based assays for safety and risk assessment studies and for new drugs development and testing. The crucial role of tissue engineering and of the new microscale technologies for improving and optimising these models, as well as the necessity of developing new protocols and analytical methods for their full exploitation, will be also discussed.
\end{abstract}

G. Mazzoleni $(\bowtie) \cdot$ N. Steimberg

General Pathology and Immunology Unit,

Department of Biomedical Sciences and Biotechnologies,

School of Medicine, University of Brescia, viale Europa 11,

25123 Brescia, Italy

e-mail: mazzolen@med.unibs.it

D. Di Lorenzo

Laboratory of Biotechnology, Civic Hospital of Brescia,

P.le Spedali Civili 1, 25123 Brescia, Italy
Keywords 3-D in vitro models - Microenvironment . Pharmaco-toxicology · Food research ·

Rotating Wall Vessel bioreactors - Microgravity ·

Tissue engineering
Abbreviations
ECM Extracellular matrix
3-D Three-dimensional
2-D Two-dimensional
RWV Rotating Wall Vessel

\section{Introduction}

The need of reliable, human-derived in vitro models alternative to the traditional animal-based studies is increasingly becoming an imperative in basic research and in the more complex fields of safety and risk assessment, as also clearly demonstrated by the new European Chemicals Legislation [53, 71]. Apart from obvious economic and ethical considerations, in vivo animal models are, in fact, progressively showing their limits: although they can mirror many aspects of human responses, they fail to reproduce others. Many pathogens are, for example, species specific (e.g. hepatitis C virus), and it is well known how a leading cause for the failure of new drugs in clinical trials is liver toxicity, which was not predicted by experimental animals [80]. Interspecies differences in metabolism and responses to regulatory signals have also raised questions about the relevance of "humanised" or transgenic animal models in predicting the behaviour of human tissues in vivo [41, 70].

Validated human-derived in vitro test models will be also of extreme value for the early prediction of nutrients 
quality and potential health effects of food and dietary supplements. The need to develop appropriate and standardised methods for the analysis of food components efficacy and safety for human health is, in fact, a widely recognised priority. Examples include bioactive peptides [29], botanical products [16] and vitamins [5]. At the same time, food industry could benefit from reliable in vitro tests that can predict in vivo adverse effects of potentially toxic contaminants (i.e. heavy metals, persistent organic pollutants, hormones, chlorination by-products, pesticides and fertilisers), or that can confirm the efficacy of methods adopted to reduce their undesirable effects. Pre-market safety and nutritional assessment procedures for genetically modified plant derived food and feed could also be improved by relevant in vitro/in vivo complementary risk approach strategies, as recently recommended by the European Food Safety Authority (EFSA; http://www.efsa. europa.eu) [22].

Finally, in the field of pharmacology, predictive cellbased assays are expected to improve the success rate at early stages of the drug-discovery process by providing cell-specific responses, which are missing in the targetoriented approach [14]. Moreover, reliable human-derived in vitro models are needed for preclinical "safety pharmacology", as outlined in ICH S7A and S7B guidance documents as well (ICH, International Conference on Harmonisation of Technical Requirements for Registration of Pharmaceuticals for Human Use; http://www.ich.org) [92].

Over 2 decades of research have demonstrated that, with respect to traditional two-dimensional (2-D) cell culture systems, three-dimensional (3-D) cell models have the potential to improve the physiological relevance of cellbased assays and to advance the quantitative modelling of biological systems from cells to living organisms [64]. For example, primary hepatocytes become undifferentiated and die within few days if cultured as 2-D monolayer; remarkably, the biosynthesis of drug metabolising enzymes, essential for the toxicity testing in pharmaceutical research, is among the first liver-specific functions to be lost [30]. Re-establishing at least some aspects of the original 3-D microenvironment allows the preservation of hepaticspecific functions for longer periods [69, 79, Mazzoleni and Steimberg, in preparation].

The rapid progress in tissue engineering and in emerging biotechnologies has enormously contributed to generate and optimise innovative 3-D cell-based models. Nevertheless, even if more physiologically relevant 3 -D in vitro systems have been developed and validated in recent years for basic research purposes, we still are far from a real strategic application of the related emerging knowledge and new technologies to safety studies, risk assessment and drug discovery fields [7]. Improvements in methods and adaptation to these advances are now required to fully exploit the benefits of the third dimension in all the fields of life sciences.

\section{Beyond the monolayer}

Limitations of traditional 2-D cell monolayers

To reproduce the phenotype of the target tissue in cultured cells is essential for obtaining reliable biomedical information [6]. Data accumulated over the past 30 years have demonstrated the significant limitations of traditional 2-D cell monolayers in predicting the behaviour of cells in living organisms; nevertheless, due to the fact that they are easy and convenient to set up, they still represent the most popular models for in vitro studies. A major limitation of 2-D monolayers is that they cannot capture the relevant complexity of the in vivo microenvironment. In fact, even if some cell types, such as epithelia, when properly cultured on flat substrates, may exhibit, at least to some extent, differentiated histoarchitecture and functions [54, 85], most cells require cues from a real 3-D environment in order to form physiologically relevant tissue-like structures in vitro [19]. Tissue-specific architecture, mechanical and biochemical signals, and cell-cell communication are lost, in fact, under the simplified 2-D conditions. Moreover, 2-D culture substrates not only fall short of reproducing the complex and dynamic environments of in vivo tissues, but also are likely to misrepresent findings to some degree by forcing cells to adapt to an artificial, flat and rigid surface.

\section{The third dimension}

In vivo, cells develop and grow within the 3-D architecture of tissues and organs. Basing on this consideration, the importance of a 3-D microenvironment in designing physiologically relevant in vitro models of living tissues has been proposed since the 1970s [9, 24, 36, 39], although the relevance of spatiotemporal cellular context during morphogenesis was already recognised by developmental biologists in the very early years of the 20th century [21].

Insights into the different properties of cells cultured in 3-D versus 2-D microenvironments were mainly made by cancer researches. Pioneers in this field, Bissell and colleagues first showed how extracellular matrix (ECM) and tissue architecture shape the way by which normal and malignant cells receive and respond to signals from the surrounding environment [12, 72, 90]. Further studies demonstrated how microenvironmental factors profoundly influence the behaviour of tumour cells, also conditioning their response/sensitivity to therapeutic agents [45, 74, 91, 93]. 
The large body of studies that have been conducted up to now on cells of various origin has clearly proved the great difference in cell function and behaviour between 2-D and 3-D culture conditions [11, 19, 57, 60, 88, 94, 95]. Also nuclear structure [52], signal transduction [32, 49, 76] and gene expression $[10,15,28,42]$ are quite dissimilar when the same cell type is cultured in 3-D models or in conventional 2-D monolayers. In 3-D systems cells develop into tissue-like structures, more similar to those formed in living organisms [11, 33, 61, 84]. Since they also demonstrated to best reproduce in vivo-like responses [8, 32, 76], 3-D systems have started to be used in a broad range of cell biology studies, including neuroscience [21], tumour biology and morphogenesis [45, 94], while their potential utility for the study of microbial pathogens-host interactions and their possible exploitation in drug development and in innovative approaches for cancer treatment has also been recently emphasised [2, 26, 59].

Microenvironment specificity and heterotypic cell interactions

While a 3-D microenvironment provides the best lifelike in vitro condition for cell and tissue culturing, other factors, such as the physical properties (stiffness) and the molecular composition of the ECM, were also demonstrated to be important regulators of the cellular behaviour and responses [32, 65-67, 86]. In addition, specific chemical morphogens, growth factors, chemokines and hormones are needed to reproduce the physiological (or pathological) complexity of an in vivo context. A 3-D matrix may both affect solute diffusion and bind many effector compounds, thereby establishing solute tissue-scale and local concentration gradients that are essential to induce cell morphogenesis and functions (see, for example [73]).

The ECM, thus, contributes to the microenvironment specificity not only through its mechanical features, but also through its own signalling moieties and its ability to bind growth factors, enzymes and other diffusible molecules. Cell-ECM interactions are therefore of pivotal importance for normal cell differentiating and functioning, but it is important to take also into account that, physiologically, a given tissue comprises multiple cell populations, that, by interacting with each other, as well as with the shared ECM, lead to unique responses in vivo. Heterotypic cell-cell interactions and the reciprocal effect of different cell populations on the whole microenvironment should be hence carefully considered in trying to establish physiologically relevant in vitro models of tissues/organs.

Ideally, seen the considerations above, each organ and tissue should require its own in vitro specific model, that should comprise a hierarchical arrangement of cells organised within a precisely defined stroma, also inclusive of microvascular networks and proper soluble factors [33].

\section{Toward tissue-like cell systems}

The evolution of 3-D models

Over the last decade 3-D culture methods have greatly increased in number, due to the rapid advances in culturing techniques emerging from the field of tissue engineering.

At the beginning, cell assembly in 3-D in vitro models resulted in the formation of multicellular spheroids, grown in suspension or on artificial substrates. Homotypic spheroids (comprised of one cell type only) showed a more "physiological" level of cell differentiation in respect to conventional 2-D culture conditions [37]. Heterotypic spheroids (composed of different cell types from the same tissue) were the first step towards the in vitro reconstruction of complex 3-D tissue equivalents. Even if they provided new insights into our knowledge of multicellular responses to physical or chemical injury [43, 77], or to the process of tumorigenesis $[48,83]$, the presence of a central hypoxic area that undergoes necrosis strongly limited their use. Central necrosis, due to mass transport restriction, toxic metabolites accumulation and lack of nutrient penetration, was also the limiting factor in the culture of organ explants. The increasing importance given to the physicochemical properties of tissue-specific microenvironments, led then many research groups to develop monotypic cell models that, in addition to cell source and medium components, carefully considered the extracellular matrix as a key element to support tissue-specific differentiated cell functions, as well. Collagen type I, fibronectin-/lamininrich basement membrane substitutes (e.g. Matrigel), reconstituted basement membranes, 3-D collagen gels, natural cell-derived 3-D extracellular matrices or fully synthetic polymeric 3-D nanostructured microenvironments have been extensively used (for a recent review on the subject, see [50]), and, even if they have added new and valuable insights to the understanding of cell functions in 3-D microenvironments (e.g. cell adhesion and migration, polarity, branching morphogenesis), yet they have not provided clear correspondence with the in vivo counterpart, whereas, unequivocally, they demonstrated the importance of matching cell types with appropriate substrata ([32, 76, 94] and references therein).

Since, beside specific matrices and other environmental factors, organs comprise multiple cell types, organotypic co-cultures that best approximate the whole tissue/organ environment have been then developed. "Skin equivalents" represent the most diffused and successful 3-D organotypic models that, effectively, have been 
productively used in pharmaco-toxicological studies (e.g. [89]) or for grafting procedures [13]. So far, other epithelial tissues have been successfully modelled in 3-D ECM cultures (see, for example [34, 95]), and heterologous 3-D organotypic cultures have been extensively used in order to study interactions between different cell types in normal and pathological conditions ([45, 67, 68] and references therein), to simulate in vitro human malignant tumours [25, 81], to investigate factors that regulate stem cell fate [17], and to learn about virus-host interactions [2].

Table 1 lists the principal 3-D cell culture systems currently employed in basic and applied research.
Increasing mass transfer

\section{Bioreactors}

It is well known that the metabolic requirements of 3-D cell constructs are substantially higher than those of flat cell monolayers, grown in static environments in liquid media.

Bioreactors were primarily developed to modulate mass transfer, a crucial element for guaranteeing gas/nutrient supply and waste elimination, essential factors for maintaining cell viability within large 3-D cell/tissue masses. Mammalian tissues are among the most difficult tissues to

Table 1 Summary of the principal currently available 3-D culture systems

\begin{tabular}{|c|c|c|c|}
\hline \multicolumn{2}{|r|}{ System } & Advantages & \multirow[b]{2}{*}{\begin{tabular}{l}
\multicolumn{1}{c}{ Disadvantages } \\
- Technically complex \\
- Need efficient perfusion \\
systems (mass transfer and \\
waste elimination is \\
variable throughout the \\
organ) \\
- Cell viability is limited to \\
few hours
\end{tabular}} \\
\hline $\begin{array}{l}\text { Whole perfused } \\
\text { organ } \\
\text { ("ex vivo" } \\
\text { model) }\end{array}$ & & $\begin{array}{l}\text { - Complex 3-D arrangement of cell-cell } \\
\text { and cell-matrix interactions is } \\
\text { preserved } \\
\text { - Closest to the in vivo situation }\end{array}$ & \\
\hline $\begin{array}{l}\text { Tissue slices / } \\
\text { Tissue explants }\end{array}$ & & $\begin{array}{l}\text { - Preserve part of tissue architecture and } \\
\text { cellular interactions } \\
\text { - Maintain tissue-specific functions for } \\
\text { longer time than perfused organ }\end{array}$ & $\begin{array}{l}\text { - Cell viability and } \\
\text { differentiated phenotype } \\
\text { are limited to few days }\end{array}$ \\
\hline $\begin{array}{l}\text { Scaffold- / } \\
\text { Microcarriers- } \\
\text { based cultures }\end{array}$ & 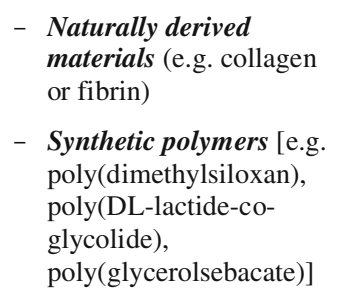 & $\begin{array}{l}\text { - Engineered scaffolds provide physical/ } \\
\text { structural/ biochemical support } \\
\text { - Sustain cell viability and tissue-like } \\
\text { functions } \\
\text { - Can be used in all dynamic/ perfused } \\
\text { culture systems }\end{array}$ & $\begin{array}{l}\text { - Spatial variations in } \\
\text { nutrients, oxygen, } \\
\text { metabolite concentrations } \\
\text { may exist and modify cell } \\
\text { behaviour randomly } \\
\text { throughout the scaffold }\end{array}$ \\
\hline \multirow{2}{*}{$\begin{array}{l}\text { Organotypic } \\
\text { cultures }\end{array}$} & Multicellular spheroids & \multirow{2}{*}{$\begin{array}{l}\text { - Reconstitution of tissue-like } \\
\text { organisation (polarity, function, } \\
\text { viability) } \\
\text { - Scaffolds can be avoided }\end{array}$} & \multirow{2}{*}{$\begin{array}{l}\text { Cell life span may vary, } \\
\text { depending on the type of } \\
\text { bioreactor }\end{array}$} \\
\hline & Cell sheet engineering a & & \\
\hline \multirow{2}{*}{$\begin{array}{l}\text { Gel- / matrix- } \\
\text { based cultures }\end{array}$} & $\begin{array}{l}\text { Hydrogels (ECM like): } \\
\text { - Natural product-based } \\
\text { hydrogels (e.g. collagen, } \\
\text { fibrin, Matrigel) } \\
\text { - Synthetic self- } \\
\text { assembling peptide } \\
\text { hydrogels }\end{array}$ & $\begin{array}{l}\text { Differentiated phenotype can be } \\
\text { maintained for several days, } \\
\text { depending on the cell type }\end{array}$ & $\begin{array}{l}\text { - Harvesting of cells could be } \\
\text { optimised } \\
\text { - Problems of mass transfer } \\
\text { if not coupled to perfused } \\
\text { systems }\end{array}$ \\
\hline & $\begin{array}{l}\text { 3-D surfaces (BM like): } \\
\text { - Synthetic (fixed } \\
\text { combination of various } \\
\text { ECM components) } \\
\text { - Cell-/ tissue-derived } \\
\text { biomatrices }\end{array}$ & $\begin{array}{l}\text { - Situation more similar to in vivo } \\
\text { conditions } \\
\text { - Sustain cell viability, polarity, } \\
\text { function }\end{array}$ & $\begin{array}{l}\text { - Composition and structure } \\
\text { of matrices may vary } \\
\text { between preparations } \\
\text { - Standardised protocols are } \\
\text { needed }\end{array}$ \\
\hline Cell suspension & & - Easiest to handle of all in vitro models & $\begin{array}{l}\text { Very limited lifespan (for } \\
\text { hepatocytes: } 2 \text { to } 4 \text { hours) }\end{array}$ \\
\hline
\end{tabular}

$E C M$ extracellular matrix, $B M$ basal membrane

${ }^{\text {a }}$ Layers of cells cultured on top of porous membranes/surfaces 
keep in vitro, due to their important and specific nutrient needs, their sensitivity to nitrogenated wastes, and their fragility to shear stress [27]. Differences between tissues also require specific culture characteristics that have to be taken into account. Oxygen tension (defect or excess) is also a limiting factor in the in vitro culture of cell/tissue constructs. A specific bioreactor configuration (design and operational conditions) should then be based on the precise evaluation of all these parameters (extensively discussed by [55]).

The first-generation bioreactors were designed to maintain 2-D tissue constructs, such as skin [31], or tissue sheets/patches [20, 82] for clinical applications. The dynamic culture conditions initially obtained by stirred tank bioreactors, were, effectively, helpful in favouring mass transport at greater depth level within the 3-D cell constructs, if compared to the conventional static environment of liquid overlay techniques. Tissue engineering gave then, with its interdisciplinary approaches, new opportunities for trying to generate 3-D mammalian cell constructs able to maintain in vitro tissue-specific differentiated functions in dynamic fluid microenvironments: complex extracellular matrices, microcarriers or scaffolds of various materials were used for promoting 3-D cell assembly and survival in spinner flasks, roller tubes and gyratory shakers. Even if hydrodynamic forces effectively increase mass transfer, nevertheless, larger cell aggregates (exceeding $1 \mathrm{~mm}$ in size) and tissue explants cultured in vitro in these experimental conditions still developed necrotic cores; moreover, a major restriction of these 3-D culture models was the detrimental effect of the high shear stress on cell viability and differentiation.

From orbitally mixed Petri dishes, to continuous stirredtank reactors, up to the more sophisticated hollow fiber (HF), coaxial HF and multi-coaxial HF, Couette-Taylor or airlift bioreactors, the technological progress allowed to improve further oxygen and nutrients supply to cultured cell/tissue structures; however, even in the case of the recently developed packed-bed bioreactors, these devices still do not allow to generate optimal conditions for the long-term culture of functional tissue-like masses (for detailed reviews on the subject see $[55,58])$. The current generation of bioreactors has, in fact, been developed to support the rapid growth of cells in solution and not the culturing of tissue engineered constructs [38].

\section{Culturing cells in microgravity: the Rotating Bioreactors}

Low-shear environment and optimal mass transfer were attained with the introduction of the Rotating Wall Vessel (RWV) bioreactors. Fruit of N.A.S.A.'s Johnson Space Center technological research in USA (http://science.nasa. gov/NEWHOME/br/bioreactor.htm), and used in groundas well as in space-based studies on a wide variety of cell types and tissues, the RWV devices are commercially available from Synthecon Inc. (Houston, USA). With no internal moving parts, the RWV bioreactors are horizontally rotating, transparent clinostats, that leave no head space between atmosphere and culture medium, therefore reducing shear forces and turbulence normally associated with impeller-driven stirred bioreactors, to a minimum; sedimentation and inadequate gas/nutrients supply are also avoided, thus guaranteeing the most favourable conditions for cell/tissue culturing [78].

RWV clinostats are equipped with a culture chamber that rotates around a horizontal axis, so that, by adjusting its rotational speed according to the specific experimental needs (e.g. sample number, density or dimensions), it is possible to obtain a stable condition where the gravitational field is time-averaged to near zero over each revolution (vector-averaged gravity), thus, effectively, negating the influence of gravitational sedimentation (balanced with centrifugation and fluid drag) and reproducing some aspects of microgravity (simulated microgravity) [46]. An optimal diffusion of gas (oxygen) inside the culture chamber is ensured by an efficient gas exchange membrane; continuous monitoring of gas supply, $\mathrm{pH}$ and temperature for culture periods ranging from several days to many months is also allowed. The RWV operational conditions can be constantly monitored and optimised during all the experimental procedures, in order to obtain a laminar flow of the fluid medium inside the culture chamber, thus reducing to a minimum the mechanical stress (shear force) on the biological samples surface; the rotational speed of the chamber can be continuously controlled, so that the samples (non-rotationally stabilized) remain in a constant orientation with respect to the chamber wall, and move in a near-solid body rotation with the fluid, thus fulfilling the requirements needed to successfully simulate microgravity condition [3]. This simulated microgravity condition facilitates space co-localisation and 3-D assembling of large cell aggregates; randomised gravitational vectors may also promote cell aggregation and differentiation processes by directly affecting gene expression or, indirectly, by facilitating autocrine/paracrine cell interactions [40].

Tissue-like 3-D constructs, as well as many different cell types from various origin and intact tissue explants, have been demonstrated to be kept efficiently in culture by the RWV bioreactors, even for long periods ([35, 59, 87]; see also Synthecon web site at http://www.synthecon.com for the latest information on the different cell types/tissues that have been successfully cultured in RWVs).

The unique microenvironment generated by the RWV bioreactors thus provide an excellent in vitro system for evaluating cell-cell and cell-matrix specific interactions, as well as for testing the influence that physical or chemical 
factors may have on cell behaviour. The utility of these devices in generating 3-D cell models for the study of human infectious disease has also been recently highlighted [59].

Synthecon also developed a spherical reactor, in which the flow conditions are non-linear [1], and a Perfused Culture System (Rotary Perfusion RCMW), that allows inline monitoring of $\mathrm{pH}$, oxygen and glucose levels and where medium can be exchanged, sampled, or modified without stopping the vessel rotation (Fig. 1); both of these devices are currently under evaluation.

\section{Tissue engineering and microtechnologies: the perspectives}

The multidisciplinary field of tissue engineering is crucial for the development of new in vitro models that can be tailored for specific applications. First, basing on quantitative analyses of cell and tissue behaviour, it can provide new information on regulatory chemical or physical signals that govern cell-cell and cell-environment responses, and, secondarily, it can develop and supply a toolbox of biomaterials, scaffolds and devices that allow the formation/ maintenance/study of accessible 3-D functional tissue structures in vitro [33]. Microscale technologies are emerging powerful tools for tissue engineering that can help in generating physiologically relevant, reproducible and well controlled cell-based systems [44]. Microfabrication techniques allowed the development of a wide range of synthetic nanostructured 3-D substrates, now available for cell culturing, that are promising for ensuring more reliable and specific 3-D microenvironments for cell models [75]. Coupling microfabrication of physically and chemically defined 3-D surfaces/scaffolds with advanced photo patterning, soft lithography techniques and microfluidics has led to a great enhancement in the complexity and biomimetic properties of engineered cell constructs [44]. Even if further significant research and technological progress is needed, the possibility to integrate these systems with devices for multiple and simultaneous microscale analysis of cell behaviour and responses, will open concrete opportunities for realising, in a next future, multifunctional 3-D cell-based platforms for a large number of applications, including screening tests [23, 56]. Cell/ tissue culture units coupled with biosensors should be used, for example, for on-line automated monitoring of environmental (e.g. gas tension, $\mathrm{pH}$, temperature) and celllinked (e.g. growth rate, density, metabolism) parameters.

Examples of the application of these new technologies that may, potentially, provide promising tools for generating adequate and cost-effective in vitro models for basic research purposes and pharmaco-toxicological needs, have been recently reported. An innovative 3-D model of human oral carcinoma, based on the use of a highly porous polymeric scaffold, was, for example, developed and tested for drug responsiveness by Fishbach et al. [25], while Ohashi et al. [63] engineered an uniformly continuous sheet of hepatic tissue, that shows liver-specific functions, using isolated primary hepatocytes cultured on temperatureresponsive surfaces. 3-D cell cultures have been also successfully used as screening tools for microscale toxicology assays [51], while Robitzki and colleagues generated and tested a 3-D multifunctional electrode-based microcavity array, which can be used for impedance spectroscopy to analyse in 3-D multicellular cultures (spheroids) cell-type specific responses to chemically active compounds [47] .

Computational fluid modelling will be a powerful tool as well, that, by contributing to generating and optimising
Fig. 1 The Perfused Culture System (Rotary Perfusion RCMW)

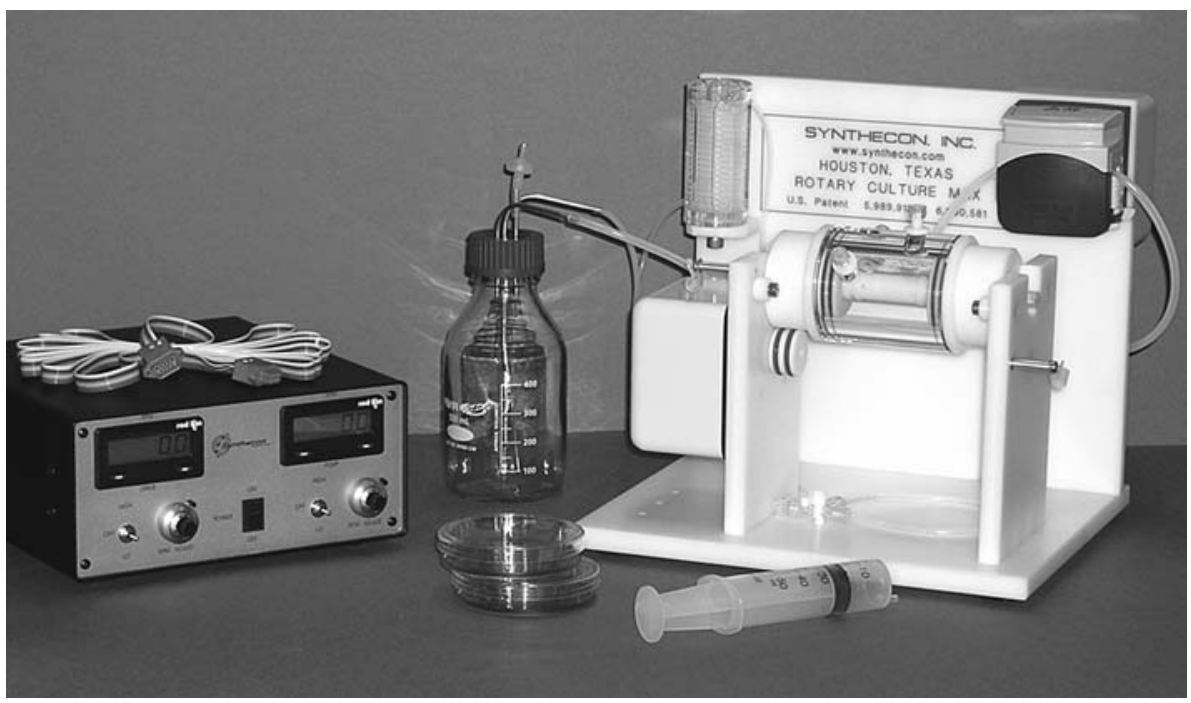


tissue engineering-related bioreactors, can be helpful in reproducing specific physiological environments for 3-D cell constructs [38]. Model systems made of different compartments configured for representing the various individual tissues/organs (functional tissue equivalents) could be then generated and hierarchically connected by controlled medium exchanges, designed to reproduce the metabolic interactions that physiologically take place between organs, thus simulating the situation of a whole living organism. To develop bioreactor systems able to mimic the complexity of the metabolism of a living organism, especially in the case of humans, represents a challenge, and, if successful, can not only be a real alternative to the use of experimental animals, but can, potentially, provide new knowledge of human metabolic processes and responses to various chemical/ physical stimuli.

In summary, the most commonly used approaches currently available to generate 3-D models, in static or in dynamic conditions, can be schematically grouped as follows: (1) organotypic explant cultures, generally kept on a substrate in the presence of media; (2) scaffold-/microcarriers-based cultures; (3) micromass cultures (homo-/ hetero-typic spheroids); (4) gel-/matrix-based techniques; (5) microfluidic systems. Table 2 illustrates advantages and disadvantages of the most commonly used static and dynamic 3-D culture systems.

\section{What else is needed}

Together with all the technological innovations in new materials and devices expected from tissue engineering, the use of 3-D culture models will also require substantial innovation in methods (e.g. of sample handling and analysis), as well as in imaging techniques [64]. Among the experimental and technical improvements that are needed to take full advantage from 3-D cell biology, a systematic collection of methods that help scientists in the transition from monolayer culture to the 3-D systems is, in fact, still lacking [33]. Reliable and standardised methods of longterm in vitro culturing of organ explants slices, that, even if depending on the need of constant supply of living tissues, have the advantage to preserve the original cytoarchitecture and the cellular differentiation of the original native tissues, thus permitting to provide tissue-specific information to a level of complexity closer to that of the intact organism, need to be optimised and validated. 3-D cell culture protocols also need to be improved and standardised, according to the biological applications they are directed at. New and more suitable methods have to be established for the analysis of 3-D systems; for example, new parameters should be defined to guarantee optimal control of culture conditions, as well as new protocols should be optimised to separate cells from the matrix to perform

Table 2 Static and dynamic systems currently employed for 3-D culture

\begin{tabular}{|c|c|c|c|}
\hline \multicolumn{2}{|r|}{ System } & Advantages & Disadvantages \\
\hline Static systems & $\begin{array}{l}\text { - Liquid overlay cultures } \\
\text { - Static matrix cultures }\end{array}$ & - No shear stress & $\begin{array}{l}\text { - Limited mass transfer } \\
\text { - Low cost } \\
\text { - Limited cell survival }\end{array}$ \\
\hline $\begin{array}{c}\text { Dynamic } \\
\text { systems }\end{array}$ & $\begin{array}{l}\text { - Roller bottles } \\
\text { - Gyratory shakers } \\
\text { - Spinner flasks }\end{array}$ & $\begin{array}{l}\text { - Moderate to high mass transfer to } \\
\text { provide nutrients and to export wastes } \\
\text { - Increase cell viability and allow long- } \\
\text { term studies }\end{array}$ & $\begin{array}{l}\text { - Intermediate to high shear } \\
\text { stress } \\
\text { - More or less expensive, } \\
\text { depending on the system in } \\
\text { use } \\
\text { - Difficult to use at large scale }\end{array}$ \\
\hline \multirow[t]{2}{*}{$\begin{array}{l}\text { Rotary cell } \\
\text { culture systems }\end{array}$} & $\begin{array}{l}\text { - Rotary Cell Culture } \\
\text { Systems (RCCS) }\end{array}$ & $\begin{array}{l}\text { - Low shear forces and turbulence } \\
\text { - High mass transfer } \\
\text { - Maintain and/or favour tissue-like } \\
\text { organisation, polarity, function } \\
\text { - Increase cell viability }\end{array}$ & - Expensive \\
\hline & - Rotary Perfusion RCMW & $\begin{array}{l}\text { - Perfusion extends RCCS potential } \\
\text { - Available as multi-compartmental } \\
\text { devices }\end{array}$ & $\begin{array}{l}\text { - Difficult to handle for } \\
\text { screening test purposes } \\
\text { - Expensive }\end{array}$ \\
\hline $\begin{array}{l}\text { Perfused } \\
\text { models }\end{array}$ & $\begin{array}{l}\text { - Hollow-fiber perfused } \\
\text { systems } \\
\text { - } \text { Airlift bioreactors } \\
\text { - Direct perfusion } \\
\text { bioreactors } \\
\text { - Packed-bed bioreactors }\end{array}$ & $\begin{array}{l}\text { - Controllable and reproducible } \\
\text { microenvironment } \\
\text { - Low to intermediate shear stress } \\
\text { - Efficient mass transfer } \\
\text { - Long-term maintenance of tissue-like } \\
\text { functions and cell viability } \\
\text { - Work with multi-compartmental } \\
\text { devices allowed }\end{array}$ & $\begin{array}{l}\text { - Limited 3-D cell growth } \\
\text { - Cost more or less significant, } \\
\text { depending on bioreactor type }\end{array}$ \\
\hline $\begin{array}{l}\text { Microfluidic } \\
\text { systems }\end{array}$ & $\begin{array}{l}\text { - Microfluidic systems } \\
\text { - Microfluidic biochips }\end{array}$ & $\begin{array}{l}\text { - See Perfused models } \\
\text { - Nutrient / fluid gradient possible } \\
\text { - Lab on chip (on-line investigations) }\end{array}$ & - Limited 3-D cell growth \\
\hline
\end{tabular}


biochemical analyses [62]. Imaging techniques that, considering the complexity of the requirements that 3-D living specimens present, can at the same time penetrate such thick (and, sometimes, scattering) samples with minimal damage and high spatial resolution, allowing, for instance, dynamic quantitative analyses of such structures, have also to be developed (discussed by [64]).

\section{Conclusions}

Physiologically relevant models for the study of normal cell/tissue functions and disease progression, as well as for the development of new therapeutic strategies or predictive toxicological investigations, should take into account that organs and tissues function in a 3-D environment, where extracellular matrix, homo- and hetero-typic cell interactions, and various biochemical and biophysical factors greatly condition cell specificity; they should also recognise that the organ itself is the unit of function. Nevertheless, a hierarchy of related models should exist that, even recognising the importance of clearly defined 3-D microenvironments, can vary with respect to their complexity to be suitable and accessible either for basic research (i.e. for identifying molecular determinants of normal organ functions and for elucidating pathways compromised during disease progression), or for pharmaco-toxicological applications (drug design and testing) [76]. In this context, the implementation of high-throughput screening procedures based on the use of simpler 3-D organotypic models, will be of great value $[4,6,48]$.

Microgravity-derived 3-D cell constructs and tissue engineering may provide, for the future, useful tools for generating reliable model systems that couple cheapness and handiness with an increased predictive power, also fostering the integration process of data from genomics, proteomics, metabolic profiling and molecular cell biology [64].

"Exploiting the third dimension" is a big challenge for the next decades in life sciences [64], and will require a more complete integration of systems biology approaches into the design and analysis of engineered tissues [18]. The rapid progress in the development of the new micro- and nano-technologies, together with the improvements in imaging technologies and in the establishment of standard experimental protocols, will certainly enhance the possibility of a rapid advance toward this objective.

Integrated and intelligent strategies involving in silico and sophisticated in vitro procedures will provide new and more efficient approaches in safety pharmacology, drug discovery and toxicity testing, as well as in all fields of food research, with consequent direct benefits for human health and undoubtable advantages in terms of industrial efficiency and animal welfare; this will be possible only if proper effort is invested in these fields, which should also be sufficiently adaptable to this change [7].

Acknowledgments The authors are thankful to Prof. Luisa Schiaffonati for her critical reading of the manuscript and to Drs. Francesca Piazza and Francesca Rovetta for their helpful English reviewing. We are also grateful to Dr. Richard Fry (Cellon S.A., Luxembourg) for his interest in our work, and for his kind and constant help in providing us the way to discover the third dimension in microgravity. This work was partially supported by European Union Grants BIOT4-CT97-2148 and LSHB-CT-2006-037168 (EXERA), and by funds of the University of Brescia to G.M.

\section{References}

1. Anderson C, Dodd C, Anderson M (2002) Inventors. Improved culture vessel having non-flat surfaces for growing or culturing cells, cellular aggregates, tissues and organoids and methods for using same. WO Patent WO 02/42409A1

2. Andrei G (2006) Three-dimensional culture models for human viral diseases and antiviral drug development. Antiviral Res 71:96-107

3. Ayyaswamy PS, Mukundakrishnan K (2007) Optimal conditions for simulating microgravity employing NASA designed rotating wall vessels. Acta Astronaut 60:397-405

4. Balis FM (2002) Evolution of anticancer drug discovery and the role of cell-based screening. J Natl Cancer Inst 94:78-79

5. Bell SJ, Grochoski GT (2008) How safe is vitamin E supplementation? Crit Rev Food Sci Nutr 48:760-774

6. Bhadriraju K, Chen CS (2002) Engineering cellular microenvironments to improve cell-based drug testing. Drug Discov Today 7:612-620

7. Bhogal N, Grindon C, Combes R, Balls M (2005) Toxicity testing: creating a revolution based on new technologies. Trends Biotechnol 23:299-307

8. Birgersdotter A, Sandberg R, Ernberg I (2005) Gene expression perturbation in vitro-a growing case for three-dimensional (3D) culture systems. Semin Cancer Biol 15:405-412

9. Bissell MJ (1981) The differentiated state of normal and malignant cells or how to define a "normal" cell in culture. Int Rev Cytol 70:27-100

10. Bissell MJ, Hall HG, Parry G (1982) How does the extracellular matrix direct gene expression? J Theor Biol 99:31-68

11. Bissell MJ, Radisky DC, Rizki A, Weaver VM, Petersen OW (2002) The organizing principle: microenvironmental influences in the normal and malignant breast. Differentiation 70:537-546

12. Bissell MJ, Rizki A, Mian IS (2003) Tissue architecture: the ultimate regulator of breast epithelial function. Curr Opin Cell Biol 15:753-762

13. Boyce ST, Warden GD (2002) Principles and practices for treatment of cutaneous wounds with cultured skin substitutes. Am J Surg 183:445-456

14. Butcher EC, Berg EL, Kunkel EJ (2004) Systems biology in drug discovery. Nat Biotechnol 22:1253-1259

15. Chang TT, Hughes-Fulford M (2008) Monolayer and spheroid culture of human liver hepatocellular carcinoma cell line cells demonstrate distinct global gene expression patterns and functional phenotypes. Tissue Eng Part A 14:1-9

16. Cefalu WT, Ye J, Wang ZQ (2008) Efficacy of dietary supplementation with botanicals on carbohydrate metabolism in humans. Endocr Metab Immune Disord Drug Targets 8:78-81

17. Chen SS, Revoltella RP, Papini S, Michelini M, Fitzgerald W, Zimmerberg J, Margolis L (2003) Multilineage differentiation of 
rhesus monkey embryonic stem cells in three-dimensional culture systems. Stem Cells 21:281-295

18. Cosgrove BD, Griffith LG, Lauffenburger DA (2008) Fusing tissue engineering and systems biology toward fulfilling their promise. Cell Mol Bioeng 1:33-41

19. Cukierman E, Pankov R, Stevens DR, Yamada KM (2001) Taking cell-matrix adhesions to the third dimension. Science 294:1708-1712

20. De Bartolo L, Jarosch-Von Schweder G, Haverich A, Bader A (2000) A novel full-scale flat membrane bioreactor utilizing porcine hepatocytes: cell viability and tissue-specific functions. Biotechnol Prog 16:102-108

21. Edelman DB, Keefer EW (2005) A cultural renaissance: in vitro cell biology embraces three-dimensional context. Exp Neurol 192:1-6

22. GMO EFSA, Panel Working Group on Animal Feeding Trials (2008) Safety and nutritional assessment of GM plants and derived food and feed: the role of animal feeding trials. Food Chem Toxicol 46(Suppl 1):2-70

23. El-Ali J, Sorger PK, Jensen KF (2006) Cells on chips. Nature 442:403-411

24. Elsdale T, Bard J (1972) Collagen substrata for studies on cell behavior. J Cell Biol 54:626-637

25. Fischbach C, Chen R, Matsumoto T, Schmelzle T, Brugge JS, Polverini PJ, Mooney DJ (2007) Engineering tumors with 3D scaffolds. Nat Methods 4:855-860

26. Fournier MV, Martin KJ (2006) Transcriptome profiling in clinical breast cancer: from 3D culture models to prognostic signatures. J Cell Physiol 209:625-630

27. Freshney RI (2000) Culture of animal cells - a manual of basic techniques, 4th edn. Wiley, New York

28. Ghosh S, Spagnoli GC, Martin I, Ploegert S, Demougin P, Heberer M, Reschner A (2005) Three-dimensional culture of melanoma cells profoundly affects gene expression profile: a high density oligonucleotide array study. J Cell Physiol 204:522-531

29. Gilani GS, Xiao C, Lee N (2008) Need for accurate and standardized determination of amino acids and bioactive peptides for evaluating protein quality and potential health effects of foods and dietary supplements. J AOAC Assoc Anal Commun Int 91:894-900

30. Gomez-Lechon MJ, Jover R, Donato T, Ponsoda X, Rodriguez C, Stenzel KG, Klocke R, Paul D, Guillen I, Bort R, Castell JV (1998) Long-term expression of differentiated functions in hepatocytes cultured in three-dimensional collagen matrix. J Cell Physiol 177:553-562

31. Green H, Kehinde O, Thomas J (1979) Growth of cultured human epidermal cells into multiple epithelia suitable for grafting. Proc Natl Acad Sci USA 76:5665-5668

32. Green JA, Yamada KM (2007) Three-dimensional microenvironments modulate fibroblast signaling responses. Adv Drug Deliv Rev 59:1293-1298

33. Griffith LG, Swartz MA (2006) Capturing complex 3D tissue physiology in vitro. Nat Rev Mol Cell Biol 7:211-224

34. Gudjonsson T, Ronnov-Jessen L, Villadsen R, Rank F, Bissell MJ, Petersen OW (2002) Normal and tumor-derived myoepithelial cells differ in their ability to interact with luminal breast epithelial cells for polarity and basement membrane deposition. J Cell Sci 115:39-50

35. Hammond TG, Hammond JM (2001) Optimized suspension culture: the rotating-wall vessel. Am J Physiol Renal Physiol 281:12-25

36. Hay ED, Dodson JW (1973) Secretion of collagen by corneal epithelium. I. Morphology of the collagenous products produced by isolated epithelia grown on frozen-killed lens. J Cell Biol 57:190-213

37. Hoffman RM (1993) To do tissue culture in two or three dimensions? That is the question. Stem Cells 11:105-111
38. Hutmacher DW, Singh H (2008) Computational fluid dynamics for improved bioreactor design and 3D culture. Trends Biotechnol 26:166-172

39. Ingber DE, Folkman J (1989) How does extracellular matrix control capillary morphogenesis? Cell 58:803-805

40. Jessup JM, Goodwin TJ, Spaulding G (1993) Prospects for use of microgravity-based bioreactors to study three-dimensional host-tumor interactions in human neoplasia. J Cell Biochem 51:290-300

41. Katoh M, Matsui T, Okumura H, Nakajima M, Nishimura M, Naito S, Tateno C, Yoshizato K, Yokoi T (2005) Expression of human phase II enzymes in chimeric mice with humanized liver. Drug Metab Dispos 33:1333-1340

42. Kenny PA, Lee GY, Myers CA, Neve RM, Semeiks JR, Spellman PT, Lorenz K, Lee EH, Barcellos-Hoff MH, Petersen OW, Gray JW, Bissel MJ (2007) The morphologies of breast cancer cell lines in three-dimensional assays correlate with their profiles of gene expression. Mol Oncol 1:84-96

43. Kerbel RS, Kobayashi H, Graham CH (1994) Intrinsic or acquired drug resistance and metastasis: are they linked phenotypes? J Cell Biochem 56:37-47

44. Khademhosseini A, Langer R, Borenstein J, Vacanti JP (2006) Microscale technologies for tissue engineering and biology. Proc Natl Acad Sci USA 103:2480-2487

45. Kim JB (2005) Three-dimensional tissue culture models in cancer biology. Semin Cancer Biol 15:365-377

46. Klaus DM (2001) Clinostats and bioreactors. Gravit Space Biol Bull 14:55-64

47. Kloss D, Fischer M, Rothermel A, Simon JC, Robitzki AA (2008) Drug testing on 3D in vitro tissues trapped on a microcavity chip. Lab Chip 8:879-884

48. Kunz-Schughart LA, Freyer JP, Hofstaedter F, Ebner R (2004) The use of 3-D cultures for high-throughput screening: the multicellular spheroid model. J Biomol Screen 9:273-285

49. Larsen M, Artym VV, Green JA, Yamada KM (2006) The matrix reorganized: extracellular matrix remodeling and integrin signaling. Curr Opin Cell Biol 18:463-471

50. Lee J, Cuddihy MJ, Kotov NA (2008) Three-dimensional cell culture matrices: state of the art. Tissue Eng Part B 14:61-86

51. Lee MY, Kumar RA, Sukumaran SM, Hogg MG, Clark DS, Dordick JS (2008) Three-dimensional cellular microarray for high-throughput toxicology assays. Proc Natl Acad Sci USA 105:59-63

52. Lelievre SA, Weaver VM, Nickerson JA, Larabell CA, Bhaumik A, Petersen OW, Bissell MJ (1998) Tissue phenotype depends on reciprocal interactions between the extracellular matrix and the structural organization of the nucleus. Proc Natl Acad Sci USA 95:14711-14716

53. Lilienblum W, Dekant W, Foth H, Gebel T, Hengstler JG, Kahl R, Kramer PJ, Schweinfurth H, Wollin KM (2008) Alternative methods to safety studies in experimental animals: role in the risk assessment of chemicals under the new European Chemicals Legislation (REACH). Arch Toxicol 82:211-236

54. Louekari K (2004) Status and prospects of in vitro tests in risk assessment. Altern Lab Anim 32:431-435

55. Martin Y, Vermette P (2005) Bioreactors for tissue mass culture: design, characterization, and recent advances. Biomaterials 26:7481-7503

56. Meyvantsson I, Beebe DJ (2008) Cell culture models in microfluidic systems. Annu Rev Anal Chem 1:14.1-14.27

57. Meshel AS, Wei Q, Adelstein RS, Sheetz MP (2005) Basic mechanism of three-dimensional collagen fibre transport by fibroblasts. Nat Cell Biol 7:157-164

58. Meuwly F, Ruffieux PA, Kadouri A, von Stockar U (2007) Packed-bed bioreactors for mammalian cell culture: bioprocess and biomedical applications. Biotechnol Adv 25:45-56 
59. Nickerson CA, Richter EG, Ott CM (2007) Studying host-pathogen interactions in 3-D: organotypic models for infectious disease and drug development. J Neuroimmune Pharmacol 2:2631

60. O'Brien LE, Jou TS, Pollack AL, Zhang Q, Hansen SH, Yurchenco P, Mostov KE (2001) Rac1 orientates epithelial apical polarity through effects on basolateral laminin assembly. Nat Cell Biol 3:831-838

61. O’Brien LE, Zegers MM, Mostov KE (2002) Opinion: Building epithelial architecture: insights from three-dimensional culture models. Nat Rev Mol Cell Biol 3:531-537

62. O'Brien LE, Yu W, Tang K, Jou TS, Zegers MM, Mostov KE (2006) Morphological and biochemical analysis of Rac1 in threedimensional epithelial cell cultures. Methods Enzymol 406:676691

63. Ohashi K, Yokoyama T, Yamato M, Kuge H, Kanehiro H, Tsutsumi M, Amanuma T, Iwata H, Yang J, Okano T, Nakajima Y (2007) Engineering functional two- and three-dimensional liver systems in vivo using hepatic tissue sheets. Nat Med 13:880-885

64. Pampaloni F, Reynaud EG, Stelzer EH (2007) The third dimension bridges the gap between cell culture and live tissue. Nat Rev Mol Cell Biol 8:839-845

65. Pankov R, Endo Y, Even-Ram S, Araki M, Clark K, Cukierman E, Matsumoto K, Yamada KM (2005) A Rac switch regulates random versus directionally persistent cell migration. J Cell Biol 170:793-802

66. Paszek MJ, Weaver VM (2004) The tension mounts: mechanics meets morphogenesis and malignancy. J Mammary Gland Biol Neoplasia 9:325-342

67. Paszek MJ, Zahir N, Johnson KR, Lakins JN, Rozenberg GI, Gefen A, Reinhart-King CA, Margulies SS, Dembo M, Boettiger D, Hammer DA, Weaver VM (2005) Tensional homeostasis and the malignant phenotype. Cancer Cell 8:241-254

68. Petersen OW, Lind Nielsen H, Gudjonsson T, Villadsen R, Ronnov-Jessen L, Bissell MJ (2001) The plasticity of human breast carcinoma cells is more than epithelial to mesenchymal conversion. Breast Cancer Res 3:213-217

69. Powers MJ, Janigian DM, Wack KE, Baker CS, Beer Stolz D, Griffith LG (2002) Functional behavior of primary rat liver cells in a three-dimensional perfused microarray bioreactor. Tissue Eng 8:499-513

70. Rangarajan A, Hong SJ, Gifford A, Weinberg RA (2004) Species- and cell type-specific requirements for cellular transformation. Cancer Cell 6:171-183

71. REACH (Registration, Evaluation, Authorisation and Restriction of Chemicals), Official Journal of the EU, L 396, vol 49, 30.12.2006

72. Roskelley CD, Desprez PY, Bissell MJ (1994) Extracellular matrix-dependent tissue-specific gene expression in mammary epithelial cells requires both physical and biochemical signal transduction. Proc Natl Acad Sci USA 91:12378-12382

73. Ruhrberg C, Gerhardt H, Golding M, Watson R, Ioannidou S, Fujisawa H, Betsholtz C, Shima DT (2002) Spatially restricted patterning cues provided by heparin-binding VEGF-A control blood vessel branching morphogenesis. Genes Dev 16:2684-2698

74. Sahai E, Marshall CJ (2003) Differing modes of tumour cell invasion have distinct requirements for Rho/ROCK signalling and extracellular proteolysis. Nat Cell Biol 5:711-719

75. Schindler M, Nur EKA, Ahmed I, Kamal J, Liu HY, Amor N, Ponery AS, Crockett DP, Grafe TH, Chung HY, Weik T, Jones E, Meiners S (2006) Living in three dimensions: 3D nanostructured environments for cell culture and regenerative medicine. Cell Biochem Biophys 45:215-227
76. Schmeichel KL, Bissell MJ (2003) Modeling tissue-specific signaling and organ function in three dimensions. J Cell Sci 116:2377-2388

77. Schwachofer JH (1990) Multicellular tumor spheroids in radiotherapy research (review). Anticancer Res 10:963-969

78. Schwarz RP, Goodwin TJ, Wolf DA (1992) Cell culture for threedimensional modeling in rotating-wall vessels: an application of simulated microgravity. J Tissue Cult Methods 14:51-57

79. Semino CE, Merok JR, Crane GG, Panagiotakos G, Zhang S (2003) Functional differentiation of hepatocyte-like spheroid structures from putative liver progenitor cells in three-dimensional peptide scaffolds. Differentiation 71:262-270

80. Sivaraman A, Leach JK, Townsend S, Iida T, Hogan BJ, Stolz DB, Fry R, Samson LD, Tannenbaum SR, Griffith LG (2005) A microscale in vitro physiological model of the liver: predictive screens for drug metabolism and enzyme induction. Curr Drug Metab 6:569-591

81. Smalley KS, Lioni M, Herlyn M (2006) Life isn't flat: taking cancer biology to the next dimension. In vitro Cell Dev Biol Anim 42:242-247

82. Sodian R, Lemke T, Loebe M, Hoerstrup SP, Potapov EV, Hausmann H, Meyer R, Hetzer R (2001) New pulsatile bioreactor for fabrication of tissue-engineered patches. J Biomed Mater Res 58:401-405

83. St Croix B, Kerbel RS (1997) Cell adhesion and drug resistance in cancer. Curr Opin Oncol 9:549-556

84. Stoker AW, Streuli CH, Martins-Green M, Bissell MJ (1990) Designer microenvironments for the analysis of cell and tissue function. Curr Opin Cell Biol 2:864-874

85. Suuronen EJ, Sheardown H, Newman KD, McLaughlin CR, Griffith M (2005) Building in vitro models of organs. Int Rev Cytol 244:137-173

86. Tomasek JJ, Gabbiani G, Hinz B, Chaponnier C, Brown RA (2002) Myofibroblasts and mechano-regulation of connective tissue remodelling. Nat Rev Mol Cell Biol 3:349-363

87. Unsworth BR, Lelkes PI (1998) Growing tissues in microgravity. Nat Med 4:901-907

88. Walpita D, Hay E (2002) Studying actin-dependent processes in tissue culture. Nat Rev Mol Cell Biol 3:137-141

89. Ward RK, Hubbard AW, Sulley H, Garle MJ, Clothier RH (1998) Human keratinocyte cultures in an in vitro approach for the assessment of surfactant-induced irritation. Toxicol In Vitro $12: 163-173$

90. Weaver VM, Petersen OW, Wang F, Larabell CA, Briand P, Damsky C, Bissell MJ (1997) Reversion of the malignant phenotype of human breast cells in three-dimensional culture and in vivo by integrin blocking antibodies. J Cell Biol 137:231-245

91. Weaver VM, Lelievre S, Lakins JN, Chrenek MA, Jones JC, Giancotti F, Werb Z, Bissell MJ (2002) beta4 integrin-dependent formation of polarized three-dimensional architecture confers resistance to apoptosis in normal and malignant mammary epithelium. Cancer Cell 2:205-216

92. Whitebread S, Hamon J, Bojanic D, Urban L (2005) In vitro safety pharmacology profiling: an essential tool for successful drug development. Drug Discov Today 10:1421-1433

93. Yamada KM, Clark K (2002) Cell biology: survival in three dimensions. Nature 419:790-791

94. Yamada KM, Cukierman E (2007) Modeling tissue morphogenesis and cancer in 3D. Cell 130:601-610

95. Zegers MM, O'Brien LE, Yu W, Datta A, Mostov KE (2003) Epithelial polarity and tubulogenesis in vitro. Trends Cell Biol 13:169-176 